\title{
KELELAHAN KERJA DAN DETERMINAN PADA PENGEMUDI MINIBUS ANTAR PROVINSI JAWA-BALI TAHUN 2019
}

\author{
Steven Adytama*, Partha Muliawan \\ Program Studi Kesehatan Masyarakat Fakultas Kedokteran Universitas Udayana \\ *email: steven.adytama@gmail.com
}

\begin{abstract}
ABSTRAK
Kelelahan kerja menjadi salah satu penyebab masalah transportasi di Indonesia dalam bentuk kejadian kecelakaan dengan angka kematian yang cukup tinggi. Tujuan penelitian ini adalah menganalisis kelelahan kerja dan determinan pada pengemudi minibus antar provinsi Jawa-Bali tahun 2019. Penelitian ini menggunakan metode cross-sectional dengan total sampel pengemudi minibus antar provinsi Jawa-Bali sebanyak 32 orang dalam satu perusahaan. Pengambilan data dilakukan secara langsung setelah pengemudi minibus tiba dipangkalan bus perusahaan di Denpasar dengan wawancara menggunakan kuesioner IFRC Jepang dan tes kecepatan waktu reaksi. Analisis data yang dilakukan adalah univariat dan bivariate menggunakan tes uji chi-square. Hasil penelitian menunjukan bahwa seluruh responden tidak mengalami kelelahan kerja secara subyektif. Hasil penelitian menunjukan bahwa seluruh responden tidak mengalami kelelahan kerja secara subyektif. Sedangkan secara obyektif responden mengalami kelelahan kerja ringan (50\%), kelelahan kerja sedang (34,38\%) dan kelelahan kerja berat $(15,63 \%)$. Proporsi kelelahan sedang dan berat secara obyektif lebih tinggi pada kelompok umur $\geq 43$ tahun dan jam kerja $>40$ jam/minggu $(\mathrm{p}<0,05)$ sedangkan status perkawinan, status gizi dan masa kerja tidak mempunyai perbedaan bermakna $(p>0,05)$. Disarankan agar untuk pengemudi minibus mengurangi jam kerja menjadi sekali perjalanan pulang-pergi dalam seminggu pada trayek jarak jauh, melakukan program medical check up dan menempatkan pada trayek lebih dekat pada pengemudi minibus yang berumur $\geq 43$ tahun.
\end{abstract}

Kata kunci: Kelelahan Kerja, Pengemudi Minibus, Antar Provinsi Jawa-Bali

\begin{abstract}
Work fatigue is one of the cause in transportation problems in Indonesia that often occurs by accidents followed by high mortality rate. The aim of this research is to analyze the work fatigue in inter-province Java-Bali province minibus driver in 2019. This study is conducted using cross-sectional method with the amount total sample of interprovince Java-Bali drivers by 32 people in one company. Data retrieval is done directly after the driver arrives at the company bus base in Denpasar by interview using Japanese IFRC questionnaire and reaction timer test. The data analysis are performed using univariate and bivariate analysis with chi-square test. The results showed that all respondents didn't experience subjective work fatigue. While objectively the respondents experienced mild work fatigue (50\%), moderate work fatigue (34.38\%) and heavy work fatigue (15.63\%). The proportion of moderate and severe fatigue was objectively higher in the age group $\geq 43$ years and working hours $>40$ hours/week $(p<0.05)$ while the marital status, nutritional status and years of service did not have a significant difference ( $p>0.05)$. It was suggested that minibus driver reduce working hours to one round trip in a week on long distance routes conduct a medical check-up program and place routes closer to the minibus driver $\geq 43$ years old.
\end{abstract}

Keywords: Work fatigue, Bus Driver, Inter-Province Java-Bali

\section{PENDAHULUAN}

Menurut ILO (2013) setiap tahun sebanyak dua juta tenaga kerja meninggal dunia karena kecelakaan kerja yang disebabkan oleh faktor kelelahan. Penelitian tersebut menyatakan dari 58.115 sampel, 32,8\% diantaranya menderita kelelahan. Hal ini juga dikatakan dalam penelitian Setyawati (2007) yang menyebutkan salah satu faktor penyebab utama kecelakaan kerja yang disebabkan oleh manusia adalah stres dan kelelahan (fatigue). Kelelahan kerja memberi kontribusi $50 \%$ terhadap terjadinya 
kecelakaan kerja. Kelelahan kerja dapat mengakibatkan terjadinya penurunan kinerja yang berakibat pada kesalahan kerja dan berujung pada kecelakaan kerja (Suma'mur, 2009).

Menurut Virdaus (2005), gejala kelelahan pada pengemudi muncul setelah menempuh perjalanan panjang disebabkan oleh banyaknya gerakan yang bersifat monoton dan dituntut selalu konsentrasi dalam mengendalikan kendaraan. Apabila keadaan tersebut terus berlanjut, maka pada suatu saat akan mengurangi kesiagaan pengemudi dan akhirnya dapat membahayakan dirinya maupun sesama pengguna jalan dan orang sekitarnya.

Berdasarkan data jumlah kecelakaan di Indonesia oleh Komite Nasional Keselamatan Transportasi pada tahun 2012-2016, jumlah korban kecelakaan akibat transportasi moda darat dengan 736 luka-luka dan 338 orang meninggal disusul dengan moda penerbangan dengan 91 luka-luka dan 299 meninggal, moda pelayaran dengan 43 luka-luka dan 216 meninggal serta moda perkeretaapian dengan 102 luka-luka dan 8 meninggal. Hal ini membuktikan bahwa jumlah kecelakaan di darat menyumbang korban terbanyak yang 70\% disebabkan oleh kelalaian pengemudi (Kemenhub RI, 2016).

Bus merupakan salah satu transportasi yang sering dipakai oleh masyarakat karena memiliki harga perjalanan yang cukup terjangkau. Transportasi bus juga tidak lepas dari risiko untuk terjadi kecelakaan lalu lintas. Dalam menjalankan tugasnya, para pengemudi bus bertanggung jawab terhadap keselamatan jiwa penumpang. Terjadinya kelalaian saat mengemudi akan menjadi penyebab terjadinya kecelakaan lalu lintas. Pengemudi bus antar provinsi dapat bekerja rata-rata sampai 10 jam dan dituntut harus memiliki konsentrasi tinggi dalam mengemudikan bus agar terhindar dari kecelakaan lalu lintas. Beban kerja itu akan meningkat jika terjadi sesuatu hal, diantaranya cuaca yang buruk dalam perjalanan, peralatan yang tidak berfungsi dengan baik, serta sistem rotasi shift yang tidak sesuai atau tidak berjalan sebagaimana mestinya. Di samping itu, pengemudi bus harus duduk dengan durasi yang cukup lama akan menciptakan kondisi lingkungan kerja yang posisi kerja statis sehingga dikhawatirkan dapat menurunkan tingkat kewaspadaan terhadap tugas yang dilaksanakannya. Walaupun jam kerja sudah diatur, namun, tiap rutinitas pasti memiliki titik jenuh. Dengan beban kerja yang tinggi tersebut, tentunya akan menyebabkan terjadinya kelelahan pada pengemudi bus antar provinsi. (Akbar, 2013)

Menurut Badan Pusat Statistik Provinsi Bali pada tahun 2017 terdapat 1.827 kejadian kecelakaan lalu lintas dengan 497 orang meninggal dunia. Fakta kejadian kecelakaan bus antar provinsi dari iNews.id Bali terjadi kecelakaan lalu lintas di Jalan Raya Denpasar-Gilimanuk tepatnya di Banjar Munduk Ranti, Desa Tukadaya, Melaya, Jembrana, Bali pada Minggu pagi 19 November 2017 oleh bus 'Malang Indah' menuju Denpasar dari Gilimanuk. Kecelakaan diakibatkan supir 
bus yang mengantuk sehingga menabrak 2 truk dan papan reklame (Sudika, 2017). Selain itu, berita dari Bali Pos pada akhir tahun 2018 tepatnya tanggal 26 Desember 2018 terjadi kecelakaan lalu lintas antara bus Bali 'Radiance' jurusan SurabayaDenpasar dengan bus 'Tiara Mas' jurusan Denpasar-Surabaya di Jalan Raya Watududol, Desa Ketapang, Banyuwangi akibat kelalaian supir bus menyebabkan 3 penumpang tewas, 12 penumpang lukaluka dan 4 diantaranya, luka berat (Wiriyanto, 2018).

Dalam penelitian ini akan dilakukan pada pengemudi minibus yang bekerja sendiri tanpa ada pengganti saat melakukan perjalanan. Sehingga pengemudi minibus memiliki risiko yang lebih besar dibandingkan dengan pengemudi bus yang memiliki pengganti dalam melakukan pergantian mengemudi dalam melakukan perjalanan. Pengemudi minibus juga melakukan pekerjaan seperti memasukan barang-barang penumpang selain mengemudi sehingga dapat meningkatkan terjadinya kelelahan kerja karena beban kerja tambahan. Kelelahan kerja saat mengemudi menjadi salah satu penyebab risiko terjadinya kecelakaan serta berdampak kesehatan dan keselamatan pengemudi minibus. Seperti yang biasa terjadi pada kasus kecelakaan lalu lintas pada bus disebabkan oleh pengemudi yang mengantuk dan tidak fokus saat melakukan perjalanan. Kondisi fisik dan psikis dari pengemudi dapat mempengaruhi konsentrasi pengemudi dalam bekerja (Ahn, 2016).

\section{METODE PENELITIAN}

Penelitian ini merupakan penelitian kuantitatif analitik dengan menggunakan pendekatan cross-sectional. Penelitian ini dilaksanakan di suatu pangkalan bus antar provinsi Jawa-Bali di Denpasar pada bulan Januari - Mei 2019.

Teknik sampling yang digunakan adalah total sampling sebanyak 32 pengemudi minibus. Sumber data yang dikumpulkan merupakan data primer kepada pengemudi minibus antar provinsi Jawa-Bali sebuah perusahaan menggunakan instrumen penelitian seperti kuesioner Industrial Fatique Rating Committee (IFRC) Jepang dan alat uji reaction timer test untuk mengukur kelelahan secara subyektif dan obyektif serta observasi status gizi dengan pengukuran berat dan tinggi badan dengan menggunakan timbangan dan pengukur tinggi badan (microtoise).

Metode analisis data penelitian ini dilakukan dengan analisis univariat dan bivariate dengan menggunakan aplikasi software statistika yaitu STATA 12. Analisis univariat dilakukan terhadap setiap variabel penelitian untuk mendistribusikan secara umum data hasil penelitian. Gambaran umum dilakukan dengan menggunakan distribusi frekuensi masing-masing variabel. Variabel yang dianalisis dengan analisis univariat adalah variabel bebas berupa umur, status perkawinan, status gizi, jam kerja dan masa kerja terhadap variabel tergantung yaitu kelelahan kerja. Sedangkan analisis bivariat dilakukan untuk melihat hubungan antara variabel terikat yang merupakan kelelahan kerja dengan 
Vol. 7 No. 2 : 107 - 118

variabel bebas yaitu faktor umur, status perkawinan, status gizi, masa kerja dan jam kerja menggunakan uji Chi Square. Semua variabel yang mempunyai nilai $\mathrm{p}<0,05$ pada analisis bivariat memiliki perbedaan bermakna. Sedangkan untuk variabel yang memiliki nilai $p>0,05$ tidak memiliki perbedaan yang bermakna pada variabel terikat yaitu kelelahan kerja.

\section{HASIL DAN DISKUSI}

\section{$\underline{\text { Karakteristik Responden }}$}

Karakteristik responden terdiri dari variabel umur, status perkawinan, status gizi, jam kerja dan masa kerja yang disajikan pada Tabel 1.
Tabel 1 menunjukan bahwa responden paling banyak berada pada kelompok umur 30-39 tahun (43,75\%) dengan rata-rata umur responden sebesar 42,87 tahun $(S D=7,02)$, berstatus kawin $(68,75 \%)$, memiliki gizi obese II dalam rentangan indeks massa tubuh $>27,0 \mathrm{~kg} / \mathrm{m} 2$ (50\%) dengan rata-rata indeks massa tubuh responden sebesar $26,8 \mathrm{~kg} / \mathrm{m} 2(\mathrm{SD}=4,91)$, memiliki jam kerja $>40$ jam/minggu $(71,88 \%)$ dengan rata-rata jam kerja responden sebesar 42,63 jam/minggu $(\mathrm{SD}=5,71)$, dan memiliki masa kerja $>10$ tahun (50\%) dengan rata-rata masa kerja responden sebesar 12,97 tahun $(\mathrm{SD}=8,66)$.

Tabel 1. Distribusi Karakteristik Responden

\begin{tabular}{lcc}
\hline \multicolumn{1}{c}{ Karakteristik Responden } & Frekuensi & Proporsi (\%) \\
\hline Kelompok Umur & 14 & 43,75 \\
30-39 tahun & 11 & 34,38 \\
$40-49$ tahun & 7 & 21,88 \\
50-59 tahun & & \\
\hline Status Perkawinan & 22 & 68,75 \\
Kawin & 1 & 3,13 \\
Belum kawin & 9 & 28,13 \\
Cerai & & \\
\hline Status Gizi & 2 & 6,25 \\
Kurus & 9 & 28,13 \\
Normal & 5 & 15,63 \\
Obese I & 16 & 50,00 \\
Obese II & & \\
\hline
\end{tabular}

Jam Kerja

$\leq 40 \mathrm{jam} / \mathrm{minggu}$

28,13

$>40$ jam/minggu

23

71,88

\section{Masa Kerja}

1-5 tahun

8

25,00 
6-10 tahun

$>10$ tahun 8
Proporsi kelompok umur responden terbanyak berada pada rentang 30-39 tahun. Menurut Tarwaka (2010), kemampuan fisik yang dimiliki seseorang yang paling optimal berada pada usia 2530 tahun, setelah itu kapasitas kerja secara fisik akan menurun setiap 1\% setiap tahun sehingga dapat mempermudah untuk terjadinya kelelahan kerja pada seseorang. Pada penelitian Damopoli (2013) mengenai faktor yang berhubungan dengan kelelahan kerja pada 45 sopir bus trayek Manado-Amurang di Terminal Malalayang Manado, ditemukan pengemudi bus terbanyak pada kelompok umur 35-39 tahun dengan 12 orang (26,7\%). Dalam penelitian ini, banyaknya pengemudi minibus berumur 30-39 tahun karena pada umur tersebut merupakan kelompok yang masih memiliki kapasitas kerja yang lebih baik daripada yang diatas 40 tahun dan memiliki kematangan emosi dan sikap dibanding dengan umur dibawah 30 tahun dikuatkan dengan data Korlantas Polri yang menyebutkan rentang usia 16-30 tahun mengalami kecelakaan lalu lintas kerena dipicu oleh perilaku ugalugalan (Prasetya, 2016).

Proporsi status perkawinan dalam penelitian ini terbanyak responden adalah dalam status kawin (68,75\%). Dalam penelitian Fadel (2014) pada pengemudi di PT. Pertamina Parepare ditemukan paling banyak dengan status kawin sebesar $81,0 \%$. Perkawinan menyebabkan meningkatnya tanggung jawab akan memiliki tugas hidup berkeluarga seperti mengatur rumah tangga, mengasuh anak dan pekerjaan. Responden yang sudah menikah dan memiliki keluarga mengalami kelelahan kerja dan setelah sampai di rumah harus melayani anak dan istrinya yang dimana waktu tersebut dapat digunakan untuk beristirahat (Fadel, 2014).

Proporsi status gizi responden terbanyak adalah obese II (50\%) yang merupakan status gizi yang tidak normal. Hasil ini sama dengan hasil penelitian Musbyarini (2010) yang sebagian besar pengemudi bus 'Sumber Alam' di Kabupaten Purworejo memiliki status gizi overweight $(32,9 \%)$ yang merupakan status gizi tidak normal. Responden penelitian ini banyak yang memiliki status gizi tidak normal disebabkan tidak memiliki waktu untuk berolahraga karena digunakan untuk istirahat dan duduk mengobrol bersama teman maupun bersenang-senang dengan tempat hiburan di Bali. Pernyataan itu diperkuat dengan data frekuensi olahraga dalam penelitian Musbyarini (2010) tentang gaya hidup dan status kesehatan pengemudi bus ditemukan paling besar 1-2 kali per minggu sebesar $46,2 \%$.

Proporsi jam kerja dalam penelitian ini terbanyak berada dalam $>40$ jam/minggu, hal ini bertentangan dengan kebijakan dari UU Nomor 13 Tahun 2003 tentang Ketenagakerjaan, dimana 
Vol. 7 No. 2 : 107 - 118

seharusnya waktu kerja maksimal 40 jam/minggu dan 8 jam/hari. Dalam penelitian Syahlefi (2014) pada pengemudi bus di CV. Makmur Medan ditemukan, durasi pengemudi yang memiliki jam kerja $>8$ jam/hari sebesar $(53,1 \%)$ yang juga bertentangan dengan kebijakan UU Nomor 13 Tahun 2003. Banyak pengemudi minibus antar provinsi Jawa-Bali memiliki jam kerja yang tidak sesuai dengan kebijakan seperti $>40$ jam/minggu karena responden sebagai pengemudi minibus yang melakukan perjalanan pulang-pergi rata-rata 2 kali dalam seminggu lalu istirahat dalam waktu 1 kali perjalanan pulang-pergi dengan waktu kerja 8-12 jam/perjalanan.

Masa kerja responden paling besar $>10$ tahun (50\%). Pada penelitian Umyati, dkk (2015) tentang kelelahan kerja pengemudi bus PT. Arimbi Jaya Agung trayek Kalideres-Merak juga memiliki masa kerja pengemudi sebagian besar $>10$ tahun (62,5\%). Banyaknya pengemudi minibus yang memiliki masa kerja yang lama dapat dikarenakan pengemudi minibus yang sudah betah dalam pekerjaannya, masih bergantung dengan pekerjaan sebagai pengemudi minibus sebagai sumber pemasukan dan pihak perusahaan kesulitan untuk mencari sumber daya manusia untuk pengemudi bus yang berkualitas untuk menggantikan pengemudi yang lama. Hal itu dikuatkan oleh data Departemen Perhubungan RI yang menyatakan kekurangan dalam mendapatkan sumber daya manusia untuk pengemudi yang berkualitas (Kemenhub RI, 2012).

\section{Kelelahan Kerja}

Pengukuran kelelahan kerja pada responden dilakukan dengan menggunakan kuesioner IFRC Jepang untuk mengukur kelelahan kerja secara subyektif dan menggunakan tes psikomotorik dengan alat reaction timer untuk mengukur kelelahan kerja secara obyektif yang dilakukan langsung setelah pengemudi bus tiba di pangkalan bus.

Tabel 2. Distribusi Kelelahan Kerja Responden

\begin{tabular}{lcc}
\multicolumn{1}{c}{ Kelelahan } & Frekuensi & Proporsi (\%) \\
\hline Kelelahan obyektif & - & - \\
Normal & 16 & 50,00 \\
Kelelahan Kerja Ringan & 11 & 34,38 \\
Kelelahan Kerja Sedang & 5 & 15,63 \\
Kelelahan Kerja Berat & & \\
\hline
\end{tabular}


Berdasarkan jumlah jawaban kuesioner IFRC Jepang, kelelahan subyektif dikelompokkan menjadi dua kategori yaitu tidak lelah (30-75) dan kelelahan (76-120). Sedangkan untuk pengukuran secara obyektif dikelompokkan menurut pengukuran waktu yang terdiri dari normal (150-240 milidetik), kelelahan kerja ringan (240-410 milidetik), kelelahan kerja sedang (410-580 milidetik), kelelahan kerja berat $(\geq 580$ milidetik). Hasil penelitian menunjukkan bahwa semua responden mengaku tidak mengalami kelelahan kerja subyektif, sedangkan secara obyektif hasil pengukuran menunjukkan semua responden dalam keadaan lelah serta proporsi terbanyak dalam kelelahan ringan (50\%) (Tabel 2). Hasil pengukuran subyektif berbanding terbalik dengan pengukuran obyektif dapat disebabkan karena responden dapat salah mengartikan kuesioner sehingga menimbulkan persepsi yang berbeda dan responden menjawab kuesioner dengan terburu-buru karena merasa terganggu atau ingin segera istirahat. Kondisi psikologis responden juga dapat mempengaruhi dalam menjawab kuesioner. Selain itu responden juga menganggap kelelahan yang dialami merupakan hal yang sepele dan dapat diatasi sendiri (Jayanthi, 2015).

Dalam pengukuran kelelahan subyektif dianalisis langsung dari gejalagejala yang dirasakan responden yang hasilnya kurang kuat, sedangkan hasil pengukuran dengan alat reaction timer dapat dikatakan lebih akurat karena menampilkan angka yang merupakan jarak waktu dari atensi dan proses kecepatan reaksi tubuh responden sehingga dapat mempresentasikan kondisi kelelahan responden (Dirgayudha, 2014).

Distribusi kelelahan kerja obyektif menurut karakteristik responden dapat dilihat pada Tabel 3, dimana kelelahan obyektif dibedakan menjadi kelelahan kerja ringan dan kelelahan kerja sedangberat. Hasil uji Chi-square menunjukan kejadian kelelahan lebih tinggi terjadi pada kelompok umur lebih tua ( $\geq 43$ tahun) dan jam kerja $>40$ jam/minggu $(p<0,05)$. Sedangkan variabel status perkawinan, status gizi dan masa kerja tidak mempunyai perbedaan yang bermakna $(\mathrm{p}>0,05)$.

Tabel 3. Distribusi Kelelahan Kerja Obyektif Menurut Karakteristik Responden

\begin{tabular}{|c|c|c|c|c|}
\hline \multirow[t]{2}{*}{ Karakteristik Responden } & \multicolumn{2}{|c|}{ Kelelahan Kerja } & \multirow{2}{*}{$\begin{array}{c}\text { Jumlah } \\
(\mathrm{n}=32)\end{array}$} & \multirow[t]{2}{*}{ Ket. } \\
\hline & $\begin{array}{c}\text { KKR } \\
(n=16)\end{array}$ & $\begin{array}{c}\text { KKS \& } \\
\text { KKB } \\
(n=16)\end{array}$ & & \\
\hline \multicolumn{5}{|l|}{ Umur } \\
\hline$<43$ tahun & $13(65 \%)$ & $7(35 \%)$ & $20(100 \%)$ & \multirow{2}{*}{$\mathrm{p}=0,028$} \\
\hline$\geq 43$ tahun & $3(25 \%)$ & $9(75 \%)$ & $12(100 \%)$ & \\
\hline \multicolumn{5}{|l|}{ Status Perkawinan } \\
\hline Kawin & $\begin{array}{c}10 \\
(45,45 \%)\end{array}$ & $12(54,55 \%)$ & $22(100 \%)$ & $\mathrm{p}=0,446$ \\
\hline
\end{tabular}


Tidak/belum kawin

Status Gizi
Normal $\left(18,5-24,9 \mathrm{~kg} / \mathrm{m}^{2}\right)$
Tidak normal $\left(<18,5 \mathrm{~kg} / \mathrm{m}^{2}\right.$ atau $\geq 25$
$\left.\mathrm{kg} / \mathrm{m}^{2}\right)$

Jam Kerja

$\leq 40 \mathrm{jam} / \mathrm{minggu}$

$>40 \mathrm{jam} / \mathrm{minggu}$

Masa Kerja

$<13$ tahun

$\geq 13$ tahun
$5(55,56 \%) \quad 4(44,44 \%) \quad 9(100 \%)$

$11 \quad 12(52,17 \%) \quad 23(100 \%) \quad p=0,694$

$(47,83 \%)$
Perbedaan bermakna menurut umur dengan kejadian kelelahan kerja sesuai dengan pernyataan Suma'mur (2009) dan Setyawati (2010) serta hasil penelitian Damopoli (2013) mengenai faktor yang berhubungan dengan kelelahan kerja pada 45 sopir bus trayek Manado-Amurang di Terminal Malalayang Manado, bahwa pengemudi yang berusia lanjut akan merasa cepat lelah dan tidak mampu bekerja secara cepat $(p=0,001)$. Menurut Suma'mur, semakin tua umur maka metabolisme dalam tubuh akan mengalami penurunan sehingga membuat tubuh lebih mudah mengalami kelelahan dan Setyawati mengemukakan bahwa faktor umur berpengaruh terhadap adanya perasaan kelelahan kerja dan perubahan waktu reaksi seorang pekerja. Untuk mengurangi kelelahan kerja yang dapat menimbulkan penuruan produktivitas kerja bahkan kecelakaan kerja, perusahaan dapat mencari pengemudi produktif yang berkualitas dan mampu bekerja dengan kekuatan otot maksimum pada rentang umur 20 sampai 29 disertai dengan pemahaman yang baik mengenai tata tertib lalu lintas.
Pemahaman dan pengetahuan tertib lalu lintas diperlukan juga pada pengemudi pada umur 20 sampai 29 tahun karena menurut penelitian Sami (2013) pada kelompok umur tersebut dan pengetahuan yang kurang ditemukan perbedaan bermakna dengan tingkat kematian kecelakaan lalu lintas lebih besar dibanding kelompok umur lainnya. Selain itu juga pada pengemudi yang berumur $\geq 43$ tahun dapat ditempatkan untuk trayek atau rute yang tidak terlalu jauh untuk mengurangi beban kerjanya.

Tidak adanya perbedaan bermakna menurut status perkawinan bertolak belakang dengan penelitian Manuel (2018) pada pengendara ojek daring di Jabodetabek dan Denpasar, yang menyatakan terdapat perbedaan bermakna antara status perkawinan dengan kelelahan kerja $(p=0,043)$. Tidak ada perbedaan bermakna antara status perkawinan dengan kelelahan kerja dapat disebabkan karena pengambilan jumlah responden yang kecil sehingga dapat memiliki kesalahan sampling yang besar 
dan daya generalisasinya yang kecil (Sutopo, 2010).

Dalam penelitian ini tidak ada perbedaan bermakna menurut status gizi sesuai dengan hasil penelitian Fadel (2014) dan Dewi (2017) mengenai faktor yang berhubungan dengan kelelahan kerja pada 42 pengemudi mobil pengangkut BBM di PT. Pertamina Parepare, bahwa tidak adanya perbedaan bermakna antara status gizi dengan kelelahan kerja $(p=0,129)$. Menurut Dewi pekerja yang memiliki status gizi yang baik (normal) berpengaruh positif terhadap daya kerja seseorang. Sebaliknya status gizi yang kurang dapat menyebabkan rendahnya ketahanan kerja ataupun perlambatan gerak dan menjadi hambatan pekerja dalam melakukan aktivitasnya. Orang yang berstatus gizi berlebih (obese) membutuhkan energi lebih besar untuk membawa tubuhnya seiring dengan kenaikan berat badannya. Tidak adanya perbedaan bermakna antara status gizi dengan kelelahan kerja dapat disebabkan karena pengemudi bus bekerja dalam posisi duduk yang sering diam sehingga terjadi penurunan kepekaan syaraf motorik sehingga mudah lelah dan terserang stress ditunjukan dengan perubahan perilaku mudah tersinggung, tidak sabar dan apatis pada pengemudi saat pengambilan data. Hal itu diperkuat dalam penelitian Ismail (2014) pada pengemudi truk tangki bahan bahak minyak di Makassar juga sejalan dengan penelitian ini yaitu tidak terdapat hubungan status gizi dengan kelelahan kerja dikarenakan adanya pengaruh stress kerja yang dialami setiap orang berbeda- beda seperti menanggapi kejadian pada saat mengemudi dijalan yang padat/macet.

Perbedaan bermakna menurut jam kerja sesuai dengan penelitian Syahlefi (2014) dalam penelitiannya mengenai faktor-faktor yang berhubungan dengan kelelahan pengemudi bus di CV. Makmur Medan, bahwa jam kerja dan kelelahan kerja memiliki hubungan perbedaan bermakna $(p=0,036)$. Pengurangan risiko kelelahan kerja pada pengemudi dapat dilakukan solusi seperti pengurangan jam kerja pada trayek yang jauh seperti Surabaya dan Malang, jika biasanya dalam seminggu pengemudi bekerja 2 kali perjalanan pulang-pergi dapat dikurangi menjadi 1 kali seminggu. Selain itu, pengemudi bus diharapkan tmelakukan istirahat saat perjalanan sekurangkurangnya setengah jam selama 4 jam berkendara terus menerus sesuai dengan Undang-Undang Nomor 13 Tahun 2003 Tentang Ketenagakerjaan karena masih ada pengemudi yang tidak beristirahat walau sudah lebih dari 4 jam mengemudikan bus.

Sedangkan variabel masa kerja tidak berbeda makna dengan kejadian kelelahan kerja $(p=0,048)$. Hasil ini juga sejalan dengan penelitian Prasetya (2016) mengenai analisis faktor risiko kelelahan kerja pada pengemudi bus antar kota antar provinsi di Perusahaan Otobus Kota Palembang, bahwa tidak adanya perbedaan bermakna antara masa kerja dengan kelelahan kerja $(p=1,00)$. Tidak terdapatnya perbedaan yang bermakna antara masa kerja dengan kelelahan kerja dapat disebabkan karena pekerja yang 
Vol. 7 No. 2 : 107 - 118

bekerja dengan masa kerja yang lama dapat banyak memiliki pengalaman dibandingkan dengan yang baru bekerja. Pekerja yang bekerja sejak lama sudah terbiasa dengan pekerjaan yang dilakukannya sehingga tidak menimbulkan kelelahan kerja bagi dirinya (Setyawati, 2010). Hal ini dikuatkan dengan oleh Widiastuti (2017) yang mengatakan dimana semakin banyak pengalaman yang diperoleh saat bekerja membuat pekerja semakin terampil dan terlatih dalam melaksanakan tugas dan pekerjaannya serta sudah nyaman dan terbiasa dengan pekerjaannya.

\section{SIMPULAN}

Karakteristik responden mayoritas berada pada kelompok umur 30-39 tahun, berstatus kawin, status gizi obese II, jam kerja $>40$ jam/minggu dan masa kerja $>10$ tahun. Semua responden mengalami kelelahan subyektif sebaliknya secara obyektif semua responden mengalami kelelahan dengan proposi terbanyak kelelahan kerja ringan (50\%). Kelelahan kerja sedang dan berat obyektif secara bermakna lebih banyak dialami oleh responden berusia lebih tua dan jam kerja diatas lebih tinggi pada kelompok umur $\geq 43$ tahun $(p=0,028)$ dan jam kerja $>40$ $\mathrm{jam} / \mathrm{minggu}(\mathrm{p}=0,049)$. Sedangkan variabel status perkawinan $(\mathrm{p}=0,446)$, status gizi $(p=0,694)$ dan masa kerja $(p=0,480)$ tidak memiliki perbedaan bermakna.

\section{SARAN}

Saran berdasarkan hasil penelitian yang sudah diperoleh dalam penelitian ini adalah perusahaan melakukan pengendalian administratif dengan pengurangan jam kerja pada pengemudi minibus dengan jam kerja $>40$ jam/minggu seperti pada trayek jarak jauh seperti Surabaya dan Malang yang biasanya 2 kali perjalanan pulang-pergi dalam seminggu menjadi 1 kali perjalanan pulang-pergi dalam seminggu dengan meningkatan penghasilan gaji pengemudi minibus dan pemberian informasi tentang pentingnya menjaga kesehatan dan keselamatan kerja, lalu perusahaan menyeimbangkan jumlah jam kerja dan istirahat seperti ditempatkan pada trayek lebih dekat sehingga menghindari kelelahan kerja dan menjaga kesehatan pengemudi bus yang berumur $\geq 43$ tahun dan Perusahaan melakukan program medical check up untuk pengemudi bus, khususnya bagi pengemudi yang berumur $\geq 43$ tahun.

\section{DAFTAR PUSTAKA}

Ahn, S., Nguyen T., Jang, H., Kim, J.G., dan Jun, S.C. (2016). Exploring NeuroPhysiological Correlates of Drivers' Mental Fatigue Caused by Sleep Deprivation Using Simultaneous EEG, ECG, and fNIRS Data. Frontier in Human Neuroscience. (10): 219.

Akbar, H. (2013). Analisis Beban Kerja Terhadap Pengemudi Bus Jurusan Bandung-Denpasar dengan Menggunakan Metode NASA-TLX. Bandung: Universitas Pasundan.

Badan Pusat Statistik Provinsi Bali. (2017). Banyaknya Kecelakaan Lalu Lintas Menurut Akibat Kecelakaan di Bali 1996-2017. Avaiable: https://bali.bps.go.id/dynamictable/20 
18/02/02/220/banyaknya-kecelakaanlalu-lintas-menurut-akibatkecelakaan-di-bali-1996-2016.html

Damopoli, F.C. (2013). Faktor-faktor yang Berhubungan dengan Kelelahan Kerja pada Pengemudi Bis Trayek ManadoAmurang di Terminal Malalayang Manado. Manado: Universitas Sam Ratulangi

Dewi, N.G.K. (2017). Tingkat Kejadian Kelelahan Kerja pada Buruh Bangunan di Proyek Como Echo Beach Hotel PT. Tunas Jaya Sanur Tahun 2017. Denpasar: Universitas Udayana.

Fadel, M. (2014). Faktor yang Berhubungan dengan Kelelahan Kerja Pengemudi Pengangkutan BBM di TBBM PT. Pertamina Parepare. Makassar: Universitas Hassanudin.

International Labour Organization. (2013). Keselamatan dan Kesehatan Sarana untuk Produktivitas: Pedoman pelatihan untuk manajer dan pekerja Modul Lima. Jakarta: ILO.

Ismail. (2014). Faktor yang Berhubungan dengan Kelelahan Kerja pada Pengemudi Truk Tangki Bahan Bakar Minyak di TBBM PT. Pertamina (Persero) Kota Makassar. Makassar: Universitas Hasanuddin.

Kementerian Perhubungan Republik Indonesia. (2016). Statistik Perhubungan 2016. Jakarta: Departemen Perhubungan Republik Indonesia.
Manuel, J.A. (2018). Faktor Risiko Kelelahan pada Pengendara Ojek Daring di Jabodetabek dan Denpasar. Denpasar: Universitas Udayana.

Musbyarini, K. 2010. Gaya Hidup dan Status Kesehatan Sopir Bus Sumber Alam di Kabupaten Purworejo, Jawa Tengah. Bogor: Jurnal Gizi dan Pangan Institut Pertanian Bogor.

Prasetya, A.Y. (2016). Analisis Faktor Risiko Kelelahan Kerja pada Supir Bus Antar Kota Antar Provinsi (AKAP) di Perusahaan Otobus (PO) Kota Palembang Tahun 2016. Palembang: Universitas Sriwijaya.

Sami, A., Moafian, G., Najafi, A., Aghabeigi M.R., Yamini, N., Heydari, S.T., dan Lankarani, K.B. (2013). Educational level and age as contributing factors to road traffic accidents. Chinese Journal of Traumalogy, (16): 281-285.

Setyawati, L. (2007). Promosi Kesehatan dan Keselamatan Kerja. Jawa Tengah: RSU Soeradji Klaten.

Setyawati, L. (2010). Selintas Tentang Kelelahan Kerja. Yogyakarta: Amara Books.

Sudika. (2017, November 19 - last update), "Sopir Ngantuk, Bus Sarat Penumpang Hantam Dua Truk Parkir", (iNews.id Bali), Avaiable: https://www.inews.id/daerah/bali/sop ir-ngantuk-bus-sarat-penumpanghantam-dua-truk-parkir/4885

Suma'mur, P.K. (2009). Higiene Perusahaan dan Kesehatan Kerja. Jakarta: Sagung Seto. 
Vol. 7 No. 2 : 107 - 118

Sutopo. 2010. Penentuan Jumlah Sampel Dalam Penelitian. Jurnal Ekonomi Managemen Akutansi STIE Dharmaputra (17): 29

Syahlefi, M.R. (2014). Faktor-faktor yang Berhubungan dengan Kelelahan Pengemudi Bus di CV. Makmur Medan Tahun 2014. Medan: Universitas Sumatera Utara.

Tarwaka. (2010). Ergonomi Industri (Dasar-dasar Pengetahuan Ergonomi dan Aplikasi di Tempat Kerja. Surakarta: Harapan Press.

Virdaus, S. (2005). Gambaran Kelelahan pada Pengemudi Angkutan Kota di
Kota Dumai Tahun 2005. Medan: Universitas Sumatera Utara.

Widiastuti. (2017). Pengaruh Pendidikan, Jumlah Jam Kerja, dan Pengalaman Kerja Terhadap Pendapatan Tenaga Kerja Lanjut Usia Di Indonesia. Yogyakarta: Universitas Negeri Yogyakarta.

Wiriyanto, B. (2018, Desember 28 - last update), “Bus Tabrakan Adu Jangkrik, Sopir Ditahan", (Bali Post), Available: http://www.balipost.com/news/2018/1 2/28/64726/Bus-Tabrakan-AduJangkrik,Sopir.html 